Print ISSN: 2288-4637 / Online ISSN 2288-4645

doi:10.13106/jafeb.2020.vol7.no12.1027

\title{
Job Performance During COVID-19 Pandemic: A Study on Indonesian Startup Companies*
}

\author{
Galih Fajar MUTTAQIN', Muhammad TAQI'², Bustanul ARIFIN ${ }^{3}$
}

Received: September 10, 2020 Revised: November 08, 2020 Accepted: November 16, 2020

\begin{abstract}
This study intends to improve job performance during the Covid-19 pandemic at startup companies in Indonesia. In this study, the variables tested were job satisfaction, job innovation, Indonesian culture control, and job performance. Increasing job performance is deemed necessary in facing the economic crisis caused by the Covid-19 pandemic. Job innovation, job satisfaction, and culture control are deemed necessary in improving job performance. The population of this study are managers of start-up companies in Jakarta, Banten, and West Java. This research data obtained by distributing questionnaires to startup managers. This is a quantitative study with primary data. The sample technique used was purposive sampling. Structural Equation Model using Partial Least Square statistical software was used to analyze data. The results of this study indicate a change in the pattern of work performed by startup companies in running their business. Before the Covid-19 pandemic, employees worked in offices for seven hours, but after this pandemic, they change work patterns, moving them to work from home. Working from home requires companies to exercise better control and leadership patterns so that employees can work comfortably.
\end{abstract}

Keywords: Empathetic Leadership, Culture Control, Job Innovation, Job Satisfaction, Performance

JEL Classification Code: O15, M41, J24

\section{Introduction}

Successful companies need employees who do more than the usual tasks and also perform beyond expectations. To maintain its survival efforts in unstable conditions, a company is required to have high capabilities. The company must survive every kind of competition and achieves its

\footnotetext{
*Acknowledgements:

The authors would like to acknowledge financial support from University of Sultan Ageng Tirtayasa for this research.

${ }^{1}$ First Author and Corresponding Author. Lecturer, Faculty of Economics and Business, University of Sultan Ageng Tirtayasa, Banten, Indonesia [Postal Address: Jl. Raya Jkt Km 4 Jl. Pakupatan, Panancangan, Kec. Cipocok Jaya, Kota Serang, Banten 42124, Indonesia]

Email: galih_fajar_muttaqin@untirta.ac.id

${ }^{2}$ Lecturer, Faculty of Economics and Business, University of Sultan Ageng Tirtayasa, Banten, Indonesia.

Email: muhamad.taqi@yahoo.com

${ }^{3}$ Associate Professor, Faculty of Economics and Business, University of Sultan Ageng Tirtayasa, Banten, Indonesia.

Email: bustanularifin1973@yahoo.com

(c) Copyright: The Author(s)

This is an Open Access article distributed under the terms of the Creative Commons Attribution Non-Commercial License (https://creativecommons.org/licenses/by-nc/4.0/) which permits unrestricted non-commercial use, distribution, and reproduction in any medium, provided the original work is properly cited.
}

competitive advantage. For this reason, strategies that are relevant to the goals that have been set should be formulated, and the implementation should be consistent to increase performance. People need support and understanding (empathy) in all aspects of life even at work (Edmondson \& Lei, 2014). Performance interpreted the level of achievement of the implementation of activity in realizing the goals, objectives, vision, and mission of the organization as outlined in the strategic planning of an organization. Performance here is related to job performance which means the work performance achieved by a person in carrying out the tasks and jobs assigned. Every organization will be required to have superior and highly competitive human resource management to produce good job performance. The role of crucial because in producing good performance in addition to maximizing their potential, managers also direct the talents, abilities, and efforts of several other people who are in their territory. Managerial performance requires the role of the manager in carrying out a series of company activities to achieve company goals. However, this does not mean that the role of subordinates in managerial performance appraisal is unnecessary. They also play a very important role in managerial performance appraisal, because they are executors of company activities. Owens and Hekman 
(2012) proved that empathetic leadership provides a model manager's support and understanding improve employees. Perceived Organizational Support and transformational leadership had effect on affective commitment and employee performance (Astuty \& Udin, 2020).

MCS is a tool designed to assist the decision-making process using formal and informal controls to achieve organizational goals. MCS is a process for a manager to ensure that resources are used effectively and efficiently. Culture Control is a group of written and unwritten values that serve as the basis for forming organizational culture and employee behavior (Ismail, 2016). Culture Control is a control system designed to create a social environment that encourages individual behavior to act and behave according to the values and norms that apply in the organization (Merchant \& David, 2007). One of the weaknesses of Culture Control is the ambiguous concept and application of culture control. This is due to the overlap between the concept of Culture Control and other forms of control (Ismail, 2016). Therefore, further and more comprehensive research is needed to determine the concept and implementation of Culture Control. Balanced Scorecard evaluate the operating performance in organizations. Balanced Scorecard has a good effect on the performance of the organization and the implementation of the same can improve employee performance (Tuan, 2020). There are internal and external factors in the company in implementing the Balanced Scorecard in evaluating performance (Troung et al., 2020).

Leaders must be able to manage employee performance properly. Leaders support a good example to their employees. Leadership is a way for a leader to influence the behavior of subordinates so that they are willing to cooperate and work productively to achieve organizational goals. People need support and empathy in all aspects of life and even at work (Edmondson \& Lei, 2014). By doing so, leaders create strong bonds that encourage and support followers in the efforts needed to improve workplace performance (Holt \& Marques, 2012). Everyone needs support and understanding (empathy) in all aspects of life, even in the workplace. Whereas in the workplace some colleagues provide support; however, the leader must also be able to give empathy to his subordinates. Leader's empathy increases job satisfaction and innovation. Empathic leadership positively moderated the relationship between job satisfaction and innovation (Kock et al., 2019). Job satisfaction reflects a positive feeling towards work and the degree to which people find satisfaction in their work. Employees who work happily without feeling overwhelmed by their work can produce optimal performance for the company because they have a good job satisfaction level and display a positive attitude towards their work. Innovation is significantly associated with performance and there significant relationship between empathic leadership and performance. A previous study revealed that culture control had a positive effect on innovation and culture control had a direct effect on performance (Ismail, 2016).

\section{Literature Review}

Leaders can also provide empathy. By doing so, leaders create strong bonds that encourage and support followers in the efforts needed to improve workplace performance (Holt \& Marques, 2012). The examination of relationship between leader empathy and performance to understand how leader empathy affects employee performance (Kock et al., 2019). Higher empathy also enables leaders to better understand and respond to follower needs in a performance-enhancing way. In other words, a leader who better understands and anticipates followers can promote good performance (Westerman et al., 2018). Empathic leadership requires that leaders express their emotional support and concern for the well-being of employees that in turn will enhance performance (Baron \& Parent, 2015). Holmes and Parker (2017) focused on how empathic leadership could affect performance.

Dehlin (2013) found that leader's empathy significantly increases team creativity and innovation. Empathic leadership positively influences job satisfaction, and higher job satisfaction provides the necessary elements for innovation. His work, while at a different analytic level, support the relationship between empathic leadership and individual innovation. In particular, empathic leadership enhances everyday innovation. Everyday innovation differs from high-level innovation in that high-level innovation occurs as the focus of one's work is supported by a leader who empathizes with his employees and creates strategiclevel technology and process (Mayfield, 2011). Employees must pay attention to their welfare with leaders who have empathy because daily innovation occur as something outside of a required job assignment and creates small improvements in routine work tasks.

Aggregate empathetic leadership positively influenced organizational innovation in manufacturing organization. Amundsen and Martinsen (2015), showed that when followers perceived positive influence at work (empathetic leadership), they would engage in more innovation every day. Judge and Kammeyer (2012) stated empathetic leadership indicates a feeling of being comfortable working in the workplace, and this feeling creates a desire to do more at work and a feeling of security about exploring new ways of doing work. Devendhiran and Wesley (2017) claimed the results of their study are in line with a broader set of studies that tested or proposed increased positive influence on workers which led to greater creative endeavors, and that leader behavior could enhance this affective status. Kock et al. (2019) stated that empathetic leadership could improve daily innovation behavior through or mediated by job 
satisfaction. Empathetic leadership is part of the emotions that are controlled through the intelligence of a leader who motivate, solve the problems of his subordinates to achieve the work targets as expected, and the leader must have a level of concern for his subordinates so that the empathy created by the leader will have an effect on the subordinates and among fellow subordinates.

Empathy is, "A feeling compassion and tenderness on seeing a victim's plight". Individuals who have a high level of empathy tend to help others to eliminate of their suffering so that they can create a new culture in a company. Empathy is an individual's ability to put they in another person's situation or an effort to understand other people feelings that have no emotional meaning for him/her. Successful organizations will have a control culture that offers supportive relationships for skilled employees and provides creative solutions to future problem to improve the ability of performance (Ismail, 2016). Organizations will need to control an open-minded culture with empathetic leaders to produce better performance. To build a good organization, we need a culture control related to leadership and the right system that allows the quality of performance to increase. Some of the organizational characteristics that will have an impact are cultural control, availability of resources, leadership that empathizes with strategy, performance, and technology.

Empathetic leadership has a strong relationship with MCS; the use of formal and informal controls will be carried out interactively to maintain performance. Senior managers use cultural control to build internal pressure, solve routine problems, and drive new strategic initiatives to build good performance. It was shown that organizational performance would give lower results when cultural control was not used as a mechanistic structure (Yuan \& Woodman, 2010). Entrepreneurial companies will continue to look for possible opportunities. Cultural control will encourage performance in entrepreneurial companies. New product availability as a result of innovation will be able to seize and maintain market share and also increase profitability and performance. Creativity, innovation, and technology are the most important ways for a company to create new value for its customers and achieve competitiveness to improve performance (Ismail, 2016).

Innovation can be a major component of corporate strategy because it plays an important role in business performance and the creation of wealth (Barsh, 2008). Innovation is closely related to the performance of companies in both the manufacturing and service industries and the entire economic sector. The ability to create and launch new products in the market is a performance driver for a successful global strategy. Thus, innovation has a positive influence on the effectiveness of organizational performance. Empathetic leadership will improve organizational performance mediated by daily innovation behavior (Kock et al., 2019).
Trying innovative behavior, especially innovation outside a normal role requires empathetic support from leaders and understanding and support for employees to feel more comfortable working to improve company performance (Mayfield \& Mayfield, 2017). This support must moderate the relationship between empathetic leadership and performance with innovation. Meanwhile, empathetic leadership increase worker motivation to try innovative and creative behavior for better performance (Perry \& Mannucci, 2017).

Problems will create stress that reduces the achievement of effective innovations. However, a leader's empathy provides a supportive climate that reduces this pressure. We have found that leader empathy improved performance by increasing job satisfaction and encouraging innovation among followers. However, research on this moderating effect is rare. Workers who receive support from empathetic leaders will be less stressed and have greater self-efficacy in their innovation efforts so that it affects employee performance. MCS consists of various control systems, one of which is culture control which is interrelated and is used efficiently to improve organizational performance. Ismail (2016) revealed that the use of culture control was influential in improving organizational performance. Besides, previous studies found that to achieve the best organizational performance, a formal and informal control system was required. Culture control is a tool to provide useful information in decision making, planning, and evaluation such that it impacts performance. Culture control is a tool for controlling the organization and directing employee behavior according to the wishes of the management to achieve organizational goals that have a direct effect on performance. Culture control is part of the MCS and functions to control the nature and behavior of employees in organizations $\mathrm{s}$ to improve organizational performance (Merchant \& David, 2007).

\section{Research Methods and Material}

This is a quantitative study using hypothesis testing for making inferences about population parameters. The population of this study is the start-up companies in Indonesia. Startup companies are used in this study because manufacturing companies are unique industries. The sample in this study were managers and employees of Indonesia startup companies. This study used a questionnaire as a data collection tool. Primary data produced in this study was obtained from respondents' responses to the study variables to be tested. The scale used in this study was the Likert scale. The statistical analysis in this study used is the Partial Least Square (PLS) software version 3 since PLS is an application used to analyze data that can provide more detailed and clear information. The number of Indonesian startup companies until the end of 2018 was 992 companies spread throughout Indonesia. 


\section{Results and Discussion}

\subsection{Statistics Results}

Respondents in this study were middle managers, top managers, and employees of startup companies in Banten, Jakarta, and West Java. According to data derived from the Indonesia Digital Creative Industry Society in 2018, the number of startup companies in the Banten, Jakarta, and West Java areas was 596 companies. Of the 596 startup companies in the Banten, Jakarta, and West Java, 120 companies had clear data and addresses and received the questionnaires.

Based on the testing data quality in Table 1 explains the Average Variance Extracted (AVE) value of the constructs of Empathetic Leadership, Culture Control, Job Innovation, Job Satisfaction, and Job Performance. It can be seen that each construct (variable) obtained an AVE value above 0.5. This indicated that each construct had a good validity value from each indicator or the questionnaire used to describe Empathetic Leadership, Culture Control, Job Innovation, Job Satisfaction. and Job Performance. This latent construct or variable obtained a composite reliability value above 0.7 on the construct variables of Empathetic Leadership, Culture Control, Job Innovation, Job Satisfaction, and Job Performance. This showed the high consistency and stability of the tools used. In other words, all of the constructs or variables of this study were fit measurement tools, and all questions used to measure each construct had good reliability.

The results of data processing using SmartPLS Original Sample showed that there was an effect of Empathetic Leadership on Indonesian Culture Control by 0.758966 which was significant with a higher T-statistic value than the T-table value $(8.516908>1.96)$. Original Sample showed that there was an effect of Empathetic Leadership on Job Innovation by 0.790412 which was significant with a higher T-statistic value than the T-table value $(10.692033>1.96)$. Original Sample showed that there was an effect of Empathetic Leadership on Job Satisfaction by 0.878187 which was significant with a higher T-statistic value than the T-table value (21.287636>1.96). Original Sample showed that there was an effect of Indonesian Culture Control on Job Performance by 0.292394 which was significant with a higher T-statistic value than the T-table value (2.898774>1.96). Original Sample showed that there was an effect of Job Innovation on Job Performance by 0.335451 which was significant with a higher T-statistic value than the T-table value (3.927472>1.96). Original Sample showed that there was an effect of Job Satisfaction on Job Performance by 0.344021 which was significant with a higher T-statistic value more than the T-table value $(3.548208>1.96)$.
Table 1: Data Quality

\begin{tabular}{|l|c|c|}
\hline & AVE & $\begin{array}{c}\text { Composite } \\
\text { Reliability }\end{array}$ \\
\hline $\begin{array}{l}\text { Empathetic Leadership } \\
(\mathrm{EL})\end{array}$ & 0,698413 & 0,920388 \\
\hline $\begin{array}{l}\text { Indonesian Culture } \\
\text { Control (ICC) }\end{array}$ & 0,583540 & 0,874911 \\
\hline Job Innovation (JI) & 0,619724 & 0,890445 \\
\hline Job Performance (JP) & 0,602194 & 0,883061 \\
\hline Job Satisfaction (JS) & 0,586864 & 0,876171 \\
\hline
\end{tabular}

Table 2: Path Coefficients

\begin{tabular}{|l|c|c|}
\hline & $\begin{array}{c}\text { Original } \\
\text { Sample (O) }\end{array}$ & $\begin{array}{c}\text { T Statistics } \\
\text { (|O/STERR|) }\end{array}$ \\
\hline $\begin{array}{l}\text { Empathetic Leadership } \\
\text { to Indonesian Culture } \\
\text { Control }\end{array}$ & 0,758966 & 8,516908 \\
\hline $\begin{array}{l}\text { Empathetic Leadership } \\
\text { to Job Innovation }\end{array}$ & 0,790412 & 10,692033 \\
\hline $\begin{array}{l}\text { Empathetic Leadership } \\
\text { to Job Satisfaction }\end{array}$ & 0,878187 & 21,287636 \\
\hline $\begin{array}{l}\text { Indonesian Culture } \\
\text { Control to Job } \\
\text { Performance }\end{array}$ & 0,292394 & 2,898774 \\
\hline $\begin{array}{l}\text { Job Innovation to Job } \\
\text { Performance }\end{array}$ & 0,335451 & 3,927472 \\
\hline $\begin{array}{l}\text { Job Satisfaction to Job } \\
\text { Performance }\end{array}$ & 0,344021 & 3,548208 \\
\hline
\end{tabular}

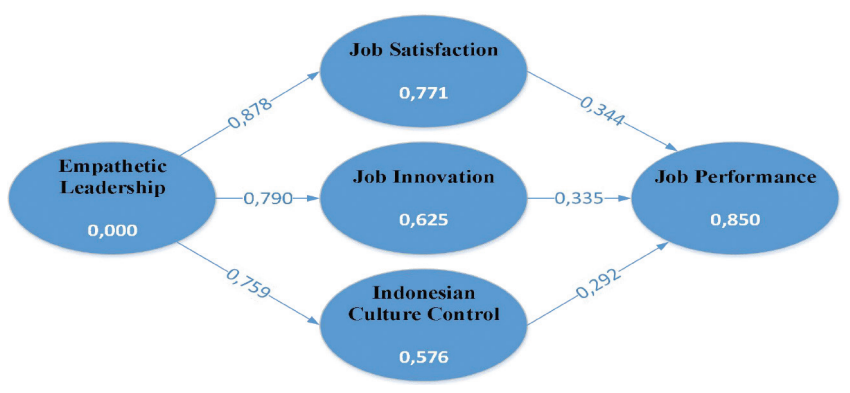

Figure 1: Model of Structural Partial Least Square 
Referring to the discussion above, hypothesis 1 was accepted. Hypothesis 1 states that there is a positive effect of empathetic leadership on job satisfaction. Empathetic leadership was evidenced to have a positive and significant effect on job satisfaction as indicated by the original sample estimate value of 0.878187 and a T-statistic of 21.287636 (higher than the t-count of 1.96). Thus hypothesis 1 was accepted. Hypothesis 2 was accepted. Hypothesis 2 states that the implementation of Empathetic Leadership has a positive and significant effect on the achievement of Job Innovation. Based on the results of data processing, it was shown that the implementation of Empathetic Leadership had a significant effect on Job Innovation which was indicated with the original sample estimate value of 0.790412 and the T-statistic value of 10.692033 which was higher than the T-table value of 1.96 , which meant that hypothesis 2 was accepted. Hypothesis 3 was accepted. In this study, Hypothesis 3 states that Empathetic Leadership has a positive and significant effect on Indonesian Culture Control. The results of data processing using the Smart PLS software are presented in Table 2. It was revealed that the parameter coefficient value of Empathetic Leadership for Indonesian Culture Control was 0.758966 and the t-statistic value of 8.516908 was higher than the t-table value of 1.96 (significant at p 0.05), thus Hypothesis 3 was accepted.

Hypothesis 4 was accepted. Hypothesis 4 in this study states that Job Innovation has a positive effect on Job Performance. The results of data processing using the Smart PLS software are presented in Table 2. The parameter coefficient value of the Job Innovation variable to Job Performance was 0.335451 and the t-statistic value was 3.927472 , which was higher than the t-table of 1.96. Thus Hypothesis 4 was accepted. Hypothesis 5 was accepted. Hypothesis 5 states that there is a positive effect of job satisfaction on job performance. Based on the results of data processing and presented in Table 2, job satisfaction had a positive and significant effect on Job Performance as indicated by the original sample estimate value of 0.344021 and a T-statistic value of 3.548208 (higher than the t-table of 1.96). Thus hypothesis 5 was accepted. Hypothesis 6 was accepted. Hypothesis 6 states that the implementation of Indonesian Culture Control had a positive and significant effect on the achievement of Job Performance. Based on the results of data processing, it was shown that the implementation of Indonesian Culture Control had a significant effect on the achievement of Job Performance as indicated by the original sample estimate value of 0.292394 and the T-statistic value of 2.898774 which was higher than the T-table of 1.96 , which meant that hypothesis 6 was accepted.

\subsection{Discussion}

Strategy is managers can influence the nature of organizational culture, external environment, technology, structural arrangements, and MCS (Chenhall, 2003). The more formal and traditional MCS is associated with strategies of conservatism, defender orientation, and cost leadership Chenhall (2003). Countries have different cultural characteristics, which in turn influence individuals in different cultures to respond to MCS in different ways (Chenhall, 2003). In recent years, both industry and academia have prioritized creativity and innovation, and research in the field has developed rapidly, yielding several interesting findings (Anderson et al., 2014). Although leadership has been routinely covered in previous studies of creativity and innovation., it's usually discussed briefly, descriptively, or noted as an area for future research (Anderson et al., 2014). Innovation must be considered by the managers to improve operational performance (Hoang \& Ngoc, 2019).

Innovation is considered by many scholars to be the main driver of organizational performance (Gunday et al., 2011). Innovative behavior was found to be positively related to organizational innovation (Choi et al., 2016). Indonesian creative products face several obstacles, including short product cycles, high competition, and ease of imitation. Most of the small and medium industries in Indonesia have a form of culture-based industry (Meutia \& Ismail, 2012). An important factor in determining organizational competitive advantage is the innovative work behavior of employees (Shin et al., 2017). In the domain of creativity research, most studies focus on the influence of leaders on employee creativity rather than on innovative work behavior (Hughes, 2018). Although transformational leadership is positively related to followers' innovative work behavior, previous studies have produced inconsistent results and meta-analytic findings showed a high variation in the relationship between transformational leadership and innovative work behavior (Uhl-Bien \& Arena, 2018).

Creativity and innovation must be recognized as the core capabilities of the company (Matolcsy \& Wyatt, 2008). The importance of leadership relates to organizational innovation and identification of related factors such as the behavior or characteristics of a leader that significantly influence organizational innovation. Previous studies revealed that leadership with its dominant role in the organization was one of the key factors that affect organizational innovation (Jung et al., 2008). Besides the importance of leadership for organizational innovation, the most important thing is to have the right type of leadership to effectively drive innovation in the organization (Oke et al., 2009). In the previous study on leadership, a series of adopted leadership behaviors 
labeled 'transformational' was considered more effective in enhancing organizational innovation than other leadership styles (Sarros et al, 2008; Hsiao et al, 2009). Another literature review showed that there was a limited concern or support for innovative behavior as a climate of innovation in organizations as a moderating factor (Gumusluoglu \& Ilsev, 2009).

Gumusluoglu and Ilsev (2009) identified that follower creativity mediated the relationship between transformational leadership and organizational innovation. Gumusluoglu and Ilsev (2009) emphasized the need for future research in this area due to several limitations in their study, including a small sample of males, with a focus on one industry, taking into account only small-sized companies and longitudinal requirement. When there is no favorable climate for innovation in organizations, transformational leader behavior can only slightly stimulate followers towards innovation (Jung et al., 2008). An organization that encouraged personnel to generate new ideas could stimulate and encourage innovation. In recent years, both industry and academia have prioritized creativity and innovation, and research in the field has developed rapidly, yielding several interesting findings (Anderson et al., 2014). Although leadership has been routinely covered in previous studies of creativity and innovation, it is usually discussed briefly, descriptively, or noted as an area for future research.

\section{Conclusion}

The conclusion of this research is Empathetic Leadership, Job Satisfaction, Job Innovation, and Indonesian Culture Control affect Job Performance. Increased innovation, job satisfaction, and supervisory supervision are needed in improving the job performance of startup companies during this pandemic.

\section{References}

Amundsen, S., \& Martinsen, L. (2015). Linking empowering leadership to job satisfaction, work effort, and creativity: The role of self-leadership and psychological empowerment. Journal of Leadership \& Organizational Studies, 22, 304-323. https://doi.org/10.1177/1548051814565819.

Anderson, N., Potocnik, K., \& Zhou, J. (2014). Innovation and creativity in organizations: A state-of-the-science review and prospective commentary. Journal of Management, 40(5), 12971333. https://doi.org/10.1177/0149206314527128.

Astuty, I., \& Udin, U. (2020), The effect of perceived organizational support and transformational leadership on affective commitment and employee performance. Journal of Asian Finance, Economics and Business, 7(10), 401-411, https://doi. org/10.13106/jafeb.2020.vol7.no10.401

Baron, L., \& Parent, E. (2015). Tevoloping Authentic Leadership Within a Training Context: Three Phenomena Supporting the Individual Development Process. Journal of Leadership and Organizational Studies, 22(1), 37-53. https://doi. org/10.1177/1548051813519501.

Barsh, J. (2008). Innovative management: A conversation with Gary Hamel and Lowell Bryan. 24-35.

Chenhall, R. H. (2003). Management control systems design within its organizational context: Findings from contingency-based research and directions for the future. Accounting Organizations and Society, 28(2-3), 127-168. https://doi.org/10.1016/S03613682(01)00027-7.

Choi, S., Kim, K., Ullah, E., \& Kang, S.-W. (2016). How transformational leadership facilitates the innovative behavior of Korean workers: Examining mediating and moderating processes. Personnel Review, 45(3), 459- 479. https://doi. org/10.1108/PR-03-2014-0058.

Dehlin, E. (2013). Fleshing out everyday innovation: Phronesis and improvisation in knowledge work. In: T.S. Pitsis, A. Simpson, \& E. Dehlin (Eds.), Handbook of Organizational and Managerial Innovation (pp.236-255). Cheltenham, UK: Edward Elgar Publishing. https://doi.org/10.4337/9781781005873.00017

Devendhiran, S., \& Wesley, J. R. (2017). Spirituality at work: Enhancing levels of employee engagement. Development and Learning in Organizations, 31(5), 9-13. https://doi.org/10.1108/ DLO-08-2016-0070.

Edmondson, A. C., \& Lei, Z. (2014). Psychological safety: The history, renaissance, and future of an interpersonal construct. Annual Review of Organizational Psychology and Organizational Behavior, 1, 23-43. https://doi.org/10.1146/ annurev-orgpsych-031413-091305.

Gumusluoglu, L., \& Ilsev, A. (2009). Transformational leadership, creativity, and organizational innovation. Journal of Business Research, 62(4), 461-473. https://doi.org/10.1016/j. jbusres.2007.07.032.

Gunday, G., Ulusoy, G., Kilic, K., \& Alpkan, L. (2011). Effects of innovation types on firm performance. International Journal of Production, 133(2), 662-676. https://doi.org/10.1016/j. ijpe.2011.05.014.

Hsiao, H. C., Chang, J. C., \& Tu, Y. L. (2009). The influence of transformational leadership and support for innovation on organizational innovation: from the vocational high school teachers' perspective. in IEEM 2009-IEEE International Conference on Industrial Engineering and Engineering Management. https://doi.org/10.1109/IEEM.2009.5373224.

Hoang, C. C., \& Ngoc, B. H. (2019). The relationship between innovation capability and firm performance in electronic companies, Vietnam. Journal of Asian Finance, Economics, and Business, 6(3), 295-304. https://doi.org/10.13106/ jafeb.2019.vol6.no3.295

Holmes, W. T., \& Parker, M. A. (2017). Empirically testing behavioral integrity and credibility as antecedents for the effective implementation of motivating language. International Journal of Business Communication, 54, 70-82. https://doi. org/10.1177/2329488416675450. 
Holt, S., \& Marques, J. (2012). Empathy in Leadership: Appropriate or Misplaced? An Empirical Study on a Topic That is Asking for Attention. Journal Of Business Ethics, 105, 95-105 https:// doi.org/10.1007/s10551-011-0951-5.

Hughes, D. J. (2018). Psychometric Validity: Establishing the accuracy and appropriateness of psychometric measures. In: P. Irwing, T. Booth \& D. J. Hughes Eds.), The Wiley handbook of psychometric testing: A multidisciplinary approach to survey, scale, and test development. Chichester, UK: Wiley. https://doi. org/10.1002/9781118489772.ch24.

Ismail, T. (2016). Culture Control, Capability, and Performance Evidence from Creative Industries in Indonesia. Asian Review of Accounting, 24(2), 171-184. https://doi.org/10.1108/ARA01-2014-0014.

Judge, T. A., \& Kammeyer-Mueller, J. D. (2012). Job attitudes. Annual Review of Psychology, 63, 341-367. https://doi. org/10.1146/annurev-psych-120710-100511.

Jung, D., Chow, C., \& Wu, A. (2008). Towards understanding the direct and indirect effects of CEOs' transformational leadership on firm innovation. The Leadership Quarterly, 19(5), 582-594. https://doi.org/10.1016/j.leaqua.2008.07.007.

Kock, N., Mayfield, M., Mayfield, J., Sexton, S., \& De La Garza, L. M. (2019) 'Empathetic Leadership: How Leader Emotional Support and Understanding Influences Follower Performance', Journal of Leadership and Organizational Studies, 26(2), $217-$ 236. https://doi.org/10.1177/1548051818806290.

Matolcsy, Z., \& Wyatt, A. (2008). The association between technological conditions and the market value of equity. The Accounting Review, 83(2), 479-518. https://doi.org/10.2308/ accr.2008.83.2.479.

Mayfield, J., \& Mayfield, M. (2017). Leadership Communication: Reflecting, Engaging and Innovating. International Journal of Business Communication, 54(1), 3-11. https://doi. org/10.1177/2329488416675446.

Mayfield, M. (2011), Encyclopedia of creativity (2 $2^{\text {nd }}$ ed.). London, UK: Academic Press. https://doi.org/10.1016/B978-0-12375038-9.00122-9.

Meutia, \& Ismail, T. (2012). The Development of Entrepreneurial Social Competence and Business Network to Improve Competitive Advantage and Business Performance of Small Medium Sized Enterprises: A Case Study of Batik Industry in Indonesia. Procedia - Social and Behavioral Sciences, 65(2), 46-51. https://doi.org/10.1016/j.sbspro.2012.11.089.

Merchant, K. A., \& Otlay, D. T. (2007). A Review of the Literature on Control and Accountability. Handbook of Management
Accounting Research. https://doi.org/10.1016/S17513243(06)02013-X.

Oke, A., Munshi, N., \& Walumbwa, F. (2009). The influence of leadership on innovation processes and activities. Organizational Dynamics, 38(1), 64-72. https://doi. org/10.1016/j.orgdyn.2008.10.005.

Owens, B. P., \& Hekman, D. R. (2012). Modeling how to grow: An inductive examination of humble leader behaviors, contingencies, and outcomes. Academy of Management Journal, 55, 787-818. https://doi.org/10.5465/amj.2010.0441

Perry-Smith, J. E., \& Mannucci, P. V. (2017). From creativity to innovation: The social network drivers of the four phases of the idea journey. Academy of Management Review, 42, 53-79. https://doi.org/10.5465/amr.2014.0462.

Sarros, J. C., Cooper, B. K., \& Santora, J. C. (2008). Building a climate for innovation through transformational leadership and organizational culture. Journal of Leadership \& Organizational Studies, 15(2), 145-158. https://doi. org/10.1177/1548051808324100.

Shin, S. J., Yuan, F., \& Zhou, J. (2017), When perceived innovation job requirement increases employee innovative behavior: A sense-making perspective. Journal of Organizational Behavior, 38(1), 68-86. https://doi.org/10.1002/job.2111.

Tuan, T. T. (2020). The Impact of Balanced Scorecard on Performance: The Case of Vietnamese Commercial Banks. Journal of Asian Finance, Economics and Business, 7(1), 7179. https://doi.org/10.13106/jafeb.2020.vol7.no1.71

Truong, D. D., Nguyen, H., \& Duong, T. Q. L. (2020). Factors Influencing Balanced Scorecard Application in Evaluating the Performance of Tourist Firms. Journal of Asian Finance, Economics, and Business, 7(5), 217-224. https://doi. org/10.13106/jafeb.2020.vol7.no5.217

Uhl-Bien, M., \& Arena, M. (2018). Leadership for organizational adaptability: A theoretical synthesis and integrative framework. The Leadership Quarterly, 29(1), 89-104. https:// doi.org/10.1016/j.leaqua.2017.12.009.

Westerman, C. Y. K., Reno, K. M., \& Heuett, K. B. (2018). Delivering feedback to supervisors' source credibility and communication competence. International Journal of Business Communication, 55, 526-556. https://doi. org/10.1177/2329488415613338.

Yuan, F., \& Woodman R. W. (2017) Innovative behavior in the workplace: the role of performance and image outcome expectations. Academy of Management Journal, 53(2), 323-342. https://doi.org/10.5465/amj.2010.49388995. 